\title{
Some Biochemical Properties of Polyphenoloxidase from Spearmint (Mentha arvensis)
}

\author{
Valdir Augusto Neves*, Douglas Gatte Picchi and Maraiza Aparecida da Silva \\ Departamento de Alimentos e Nutrição; Faculdade de Ciências Farmacêuticas; Universidade Estadual Paulista; \\ Rodovia Araraquara Jaú Km 1; São Paulo - SP - Brasil
}

\begin{abstract}
Polyphenoloxidase (PPO; EC 1.14.18.1) extracted from Mentha arvensis leaves was isolated by $\left(\mathrm{NH}_{4}\right)_{2} \mathrm{SO}_{4}$ precipitation and extensive dialysis. Its optimum $\mathrm{pH}$ and temperature varied with the substrate. The PPO showed activity with various diphenols. Km values were found 0.825, 0.928 and 7.41mM for caffeic acid, 4-methylcatechol and catechol, respectively. On heat-inactivation, half of the activity was lost after 60 and 15 sec at 70 and $75^{\circ} \mathrm{C}$, respectively. Measuring of residual activity showed a stabilizing effect of sucrose at various temperatures with activation energy (Ea) for inactivation increasing with sucrose concentration from 0 to $40 \%$ (w/w). Ea values of 78.13; 80.37; 82.79 and $81.00 \mathrm{~kJ} / \mathrm{Mol}$ were found for 0, 15; 30 and 40\% sucrose, respectively. PPO was inhibited by ascorbic, benzoic, cinnamic, ferulic, p-coumaric, protocatechuich acids, sodium metabisulfite, pyrogallol and resorcinol. The Ki values showed that ascorbic acid was the most effective inhibitor. The type inhibition was determined for each inhibitor.
\end{abstract}

Key words: polyphenoloxidase; Mentha arvensis; characterization; heat inactivation; inhibitors

\section{INTRODUCTION}

Polyphenoloxidase

(PPO,

monophenol, dydhydroxy-L-phenylalanine oxygen oxidoreductase, E.C. 1.14.18.1) is an enzyme that catalyzes the oxidation of mono-, di- and polyhydric phenols to o-quinones. Different names have been associated with this enzyme including tyrosinase, cresolase, catecholase, diphenolase and phenolase. The enzyme is widely distributed on the phylogenic scale and responsible for the deleterious effect of enzymatic browning reactions in foods and other materials. It is well known that browning reactions, initiated by the enzyme, occur generally post-harvest when the tissues are exposed either to stress conditions, to deterioration or during handling, storage and processing (TomásBarberán and Espín, 2001). PPO has been extensively studied and characterized in a variety of tissues, as sweet potato (Lourenço et al., 1992) potato and taro (Duangmal and Owusu Apenten, 1999); egg plant (Concellón et al., 2004); palmito (Lourenço et al., 1990); apple (Nicolas et al., 1994); pears (Gauillard and Richard-Forget, 1997); grapes (Rapeanu et al., 2006); herbs (Arslan et al., 1997); tea leaves (Halder et al., 1998); peppermint (Kavrayan and Aydemir, 2001); oregano (Dogan et al., 2005) and artichoke (Aydemir, 2004). Mentha arvensis is the Mentha specie extensively cultivated in Brazil for the industrial and home uses as tea infusion. It has a great number of uses as medicinal crop, refreshing flavouring agent for foods, candy, gum and dental products. To date,

\footnotetext{
Author for correspondence: nevesva@fcfar.unesp.br
} 
there are no studies reported on the isolation and characterization on PPO from $M$. arvensis leaves. The present study was conducted to obtain information on PPO from this source and describes some properties of the enzyme and the inhibitory effect of various substances.

\section{MATERIALS AND METHODS}

\section{Plant material and chemicals}

The Mentha leaves were harvested fresh from the botanic garden of Faculty of Pharmaceutical Sciences-UNESP. The leaves were washed with distilled water, dried on filter paper and stored at $4^{\circ} \mathrm{C}$ before use. The fresh leaves were weighted and used for the preparation of the enzyme extracts.

Catechol, 4-methylcatechol, ascorbic acid, sodium metabisulfite, mercaptoethanol, DL-DOPA, dethioerythritol, L-tyrosine, Triton X-100, cinnamic, p-coumaric, ferulic, caffeic, protocathechuic, benzoic acid, resorcinol, pyrogallol were obtained from Sigma Chemical Co. (St. Louis, USA). All other chemicals used were analytical reagent grade.

\section{Enzymes extraction and partial purification}

Fresh leaves $(5 \mathrm{~g})$ were grinding in a mortar followed by Ultra-turrax homogenization in $15 \mathrm{ml}$ $0.05 \mathrm{M}$ of phosphate buffer ( $\mathrm{pH}$ 6.0) containing $0.030 \mathrm{M}$ ascorbic acid, $0.35 \mathrm{M} \mathrm{KCl}, 0.5 \%$ TRITON $\mathrm{X}-100$ and policlar aT $(0.1 \mathrm{~g} / \mathrm{g})$ as phenolic scavengers. The homogenates were filtered through two layers of cheese-cloth and centrifuged at $10.000 \mathrm{~g}$ for $40 \mathrm{~min}$ at $4^{\circ} \mathrm{C}$. $\left(\mathrm{NH}_{4}\right)_{2} \mathrm{SO}_{4}$ was added to the supernatant to obtain $20-90 \%$ saturation with gentle stirring and centrifuged at $10.000 \mathrm{~g}$ for 40 min at $4^{\circ} \mathrm{C}$. The protein fraction that precipitated was dissolved in $0.05 \mathrm{M}$ of phosphate buffer $(\mathrm{pH}$ 7.0), containing $0.030 \mathrm{M}$ ascorbic acid and dialyzed at $4{ }^{\circ} \mathrm{C}$ for $22 \mathrm{~h}$ against the same buffer containing $0.010 \mathrm{M}$ ascorbic acid. The dialyzed sample was used as the PPO enzyme source in the experiments.

\section{Enzyme assay}

PPO activity was determined by measuring the initial rate of quinone formation as indicated by an increase in absorbance at $420 \mathrm{~nm}$ at $30^{\circ} \mathrm{C}$ for $4-$ methylcatechol (4-methyl-1,2-benzenediol) as substrate (Lourenco et al., 1990). An Ultrospec 2000 (Pharmacia Biotech) spectrophotometer was employed throughout the experiment. The reaction mixture contained $0.002 \mathrm{M}$ 4-methylcathecol, 0.05 $\mathrm{M}$ phosphate buffer ( $\mathrm{pH}$ 6.0), and enzyme solution in a total volume of $3 \mathrm{~mL}$ in the cuvette. The initial rate of the enzyme-catalysed reaction was a linear function of time for $3 \mathrm{~min}$. In all determinations, PPO activity was assayed in triplicate measurements and one unit was defined as a change of 0.001 absorbance unit per min.

\section{Protein determination}

Protein concentration of the various extracts and solutions was determined by the dye-binding method of Bradford (1976) using bovine serum albumin as standard.

\section{Effect of temperature/thermal stability}

PPO activity as a function of temperature was determined from 5 to $60^{\circ} \mathrm{C}$. The heat inactivation studies were performed over the range of $50-80^{\circ} \mathrm{C}$. After heating for a given period, the enzyme aliquot was cooled and immediately assayed as described above. To study the effect of additives on heat stability, PPO was incubated in the presence of sugar followed by the determination of the remaining activity. The constant rates $(\mathrm{k})$ for inactivation were determined from the slopes of the time course denaturation according to: $\log$ (A/Ao $.100)=-(\mathrm{k} / 2.303) \mathrm{t}$ or $\ln (\mathrm{A} / \mathrm{Ao})=-\mathrm{kt}$, where Ao is the initial enzyme activity and $\mathrm{A}$ is the activity at the time measured. The slopes of these plots were determined by linear regression and the constant rates were calculated by replotting. The apparent activation energies (Ea) were calculated from the slopes of the Arrhenius plots: $\ln \mathrm{k} x$ 1/T according to the equation $\ln \mathrm{K}=-\mathrm{Ea} / \mathrm{RT}$, where $\mathrm{R}$ is the gas constant $\left(8.314 \mathrm{~J} \mathrm{Mol}^{-1} \mathrm{~K}^{-1}\right), \mathrm{T}$ is the temperature in Kelvin. Slopes were calculated by linear regression. The apparent activation energy $(\mathrm{Ea})$ for inactivation was also performed by measuring the reaction rate constant for inactivation at different temperatures in the presence and absence of sucrose as additive. All of the assays were performed in triplicate.

\section{pH optimum and stability}

PPO activity as a function of $\mathrm{pH}$ was determined using 4-methylcatechol, catechol and caffeic acid as substrates. Phosphate and phosphate-citrate buffer, ranging from $\mathrm{pH} 3.0$ to 8.0 was used at the assays. The $\mathrm{pH}$ stability was determined by incubating the enzyme in the above buffer $(\mathrm{pH} 3.0$ to 8.0 ) for $30 \mathrm{~min}$ and at the end of the incubation 
period, samples were taken and assayed under standard conditions as described above. All of the assays were performed in triplicate.

\section{Substrate specificity and kinetic studies}

Michaelis-Menten constant $\left(\mathrm{K}_{\mathrm{m}}\right)$ and maximum reaction velocity $\left(\mathrm{V}_{\max }\right)$ of Mentha PPO were determined using various substrates (catechol, 4methylcatechol, caffeic, protocatechuic, cinnamic acids, tyrosine, pyrogallol and resorcinol, in each own wavelength). Data were plotted as $1 / \mathrm{V} \times 1 / \mathrm{S}$ concentration according to the method of Lineweaver and Burk (1934). All of the assays were performed in triplicate.

\section{Effect of various inhibitors in the activity}

The effect of inhibitors (ascorbic, caffeic, pcoumaric, ferulic, protocatechuic, benzoic acids, resorcinol, pyrogallol, sodium metabisulfite) on PPO activity was measured in the standard reaction medium in the presence and absence of different concentrations of the substances. Using two different concentrations of substrates, PPO activity was assayed at various concentrations of the substances. Values of $1 / \mathrm{V} \times$ [i] concentration were plotted and the $\mathrm{Ki}$ determined according to the method of Dixon (1953). All of the assays were performed in triplicate.

\section{SDS activation}

Enzyme extract was incubated with sodium dodecyl-sulphate (SDS) at various concentrations for $5 \mathrm{~min}$, followed by the determination of the enzyme activity as described above. SDS concentrations in the incubation medium were varied from 0.01 to $0.1 \%$.

\section{RESULTS AND DISCUSSION}

The extraction of PPO from the leaves of $M$. arvensis needed the addition of browning inhibitors because the tanning reactions caused partial inactivation of the enzymes and/or also rendered the extract browned. Various compounds were tested in the extraction medium as 2mercaptoethanol, PEG 6000, dithioeritrithol, metabisulfite. However, some of them inactivated the enzyme or did not interact with phenolics and produced various degree of browning. The higher yields of PPO activity associated with a lower browning was obtained in the $\mathrm{pH}$ range of 5.5-7.0, with phosphate buffer $0.05 \mathrm{M}$ containing $0.030 \mathrm{M}$ ascorbic acid, $0.35 \mathrm{M} \mathrm{KCl}$, addition of Policlar aT $(0.1 \mathrm{~g} / \mathrm{g})$ and $0,5 \%$ Triton X-100. Since PPO precipitated in a broad ammonium sulfate saturation range (20-90\%), followed by extensive dialysis $(22 \mathrm{~h})$. This preparation was used as the source of enzyme for the studies. The PPO activity can be assayed in the presence or absence of SDS (Moore and Flurkey, 1990; Nunez-Delicado et al., 2003; Concellón et al., 2004). The effect of SDS in the activation process results from a conformational change due to the binding of a small quantity of SDS to the active site (Moore and Flurkey, 1990, Gauillard and Richard-Forget, 1997). Nunez-Delicado et al. (2003) related a latent form of PPO in persimmon fruit that was optimally activated by the presence of $1 \mathrm{mM}$ SDS; the latent enzyme presented monophenolase and diphenolase activities and in the absence of SDS the enzyme activity increased at acidic $\mathrm{pH}$. Sodium dodecyl sulphate from 0.01 to $0.1 \%$ concentration was tested in the assay of mentha PPO, but it did not affect the activity (data not shown). This indicated that the mentha PPO was fully active without the presence of a latent form of the enzyme.

\section{pH optima}

Optimum $\mathrm{pH}$ for PPO activity with caffeic acid, 4methylcatechol and catechol as substrates were $\mathrm{pH}$ 4.5, 5.0 and 6.5, respectively (Fig 1). However, when using 4-methylcatechol at $\mathrm{pH} 3.5$ and 8.0, the enzyme still retained 15 and $30 \%$ of the optima activity. Differences in optimum $\mathrm{pH}$ for PPO with distinct substrates have been reported for the enzyme from various sources (Lourenço et al., 1990; Gonzalez et al., 2000; Kavrayan and Aydemir, 2001; Nunez-Delicado et al., 2003; Dogan et al., 2005; Rapeanu et al., 2006). However, for 4-methylcatechol, $\mathrm{pH}$ optima of 4.0; 5.7 and 6.5 were found for sweet potato (Lourenco et al., 1992), egg plant (Concellón et al., 2004) and longan fruit (Jiang, Yue-Ming, 1999), respectively.

\section{The effect of temperature on PPO activity}

Optimum temperature for PPO activity with caffeic acid and catechol was $30^{\circ} \mathrm{C}$; however, when using 4-methylcathecol as substrate, it was $15^{\circ} \mathrm{C}$ (Fig 2). This surprising behavior of the PPO enzyme with the last substrate was confirmed after several repetitions. Heating for $30 \mathrm{~min}$ at $30^{\circ} \mathrm{C}$ caused no changes in the activity; however, at the higher temperatures, the enzyme was rapidly inactivated. Optimum temperatures for PPO activity in others sources were reported to be between 20 and $40^{\circ} \mathrm{C}$ 
(Rapeanu et al., 2006, Lourenco et al., 1992, Kavrayan and Aydemir, 2001).

Dogan et al., 2005, Concellón et al., 2004,

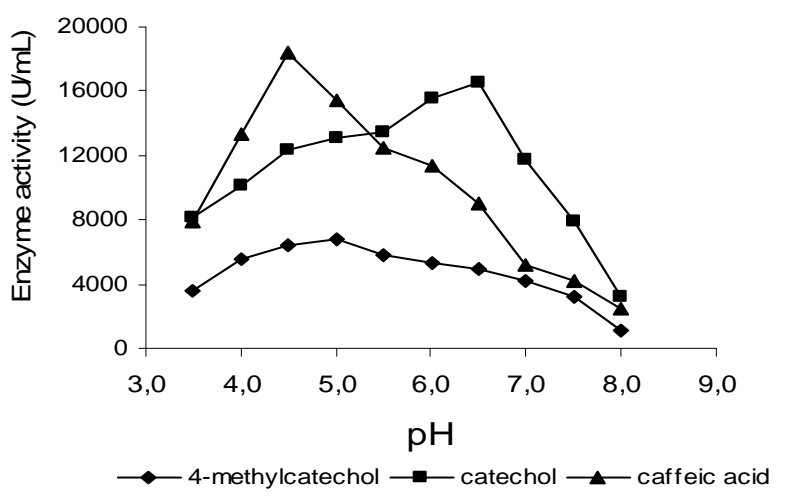

Figure 1 - Activity of Mentha arvensis PPO as a function of $\mathrm{pH}$ for different substrates. Assay conditions described in methods.

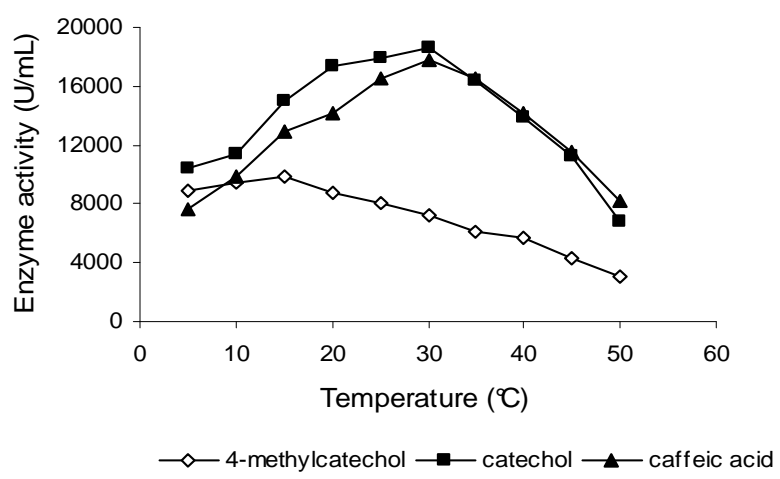

Figure 2 - Effect of temperature on Mentha arvensis PPO activity for different substrates. Assay conditions described in methods.

The enzyme was reasonably stable at $60^{\circ} \mathrm{C}$ and, as expected, the rate of inactivation was higher with increasing temperature (Fig. 3). When exposed to $65^{\circ} \mathrm{C}$, a $65 \%$ residual activity was registered for 60 sec, in contrast to 30 and $15 \mathrm{sec}$ at 70 and $75^{\circ} \mathrm{C}$, respectively. The times required for $50 \%$ inactivation of $\mathrm{PPO}$ activity at $70^{\circ} \mathrm{C}$ and $75^{\circ} \mathrm{C}$ were 60 and $15 \mathrm{sec}$, respectively (Fig. 3). The mentha PPO showed a biphasic thermal inactivation behavior to 60,65 and $70^{\circ} \mathrm{C}$. However, several workers imputed this character non-linear to the formation during the heating of denaturated protein forms and groups of PPO molecule that remained active (Neves and Lourenço, 1998, Hemeda and Klein, 1991, VamosVigyázo, 1981).

Contrary to peroxidases, PPO is not a heat-stable enzyme (Vamos-Vigyázo, 1981). The half-life of the mentha PPO at $70^{\circ} \mathrm{C}$ was similar to PPO from other sources such as taro and potato (Duangmal and Owusu Apenten, 1999) grape (Rapeanu et al., 2006) and less resistant to heating than PPO from peppermint (Kavrayan and Aydemir, 2001) sweet potato (Lourenço et al., 1992) and palmito (Lourenço et al., 1990). 


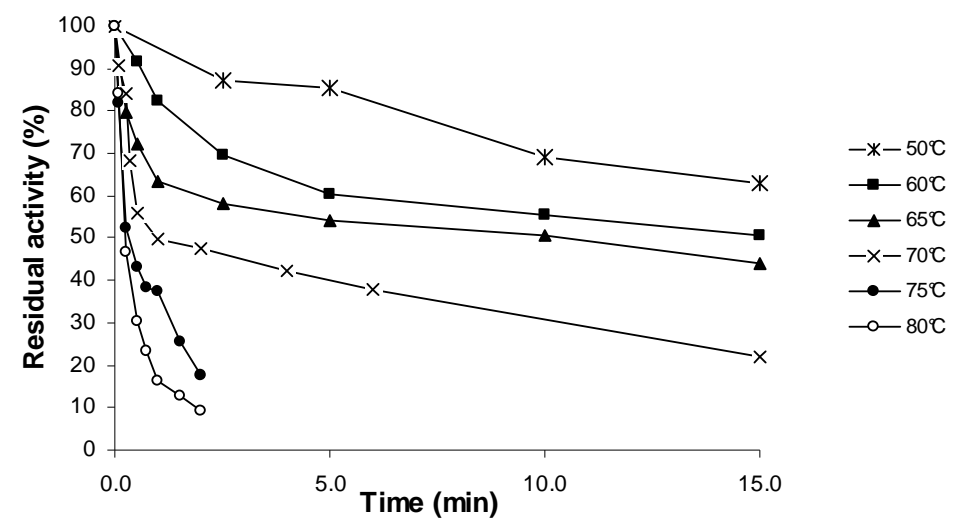

Figure 3 - Heat inactivation of Mentha arvensis PPO at different temperatures. The enzyme was incubated at the temperatures $\left(50-80^{\circ} \mathrm{C}\right)$ and the remaining activity was determined with 4-methylcatechol as substrate.

The effect of sugars on heat stability and activation energy

The enzyme was heated at $70,75,80,85$ and $90^{\circ} \mathrm{C}$ in the presence and absence of sucrose at $0,15,30$ and $40 \%$ concentration $(\mathrm{w} / \mathrm{w})$ in the incubation mixture. A rise in sucrose concentration corresponded to an increase in enzyme stability regardless of the heating temperature, when compared to control without sugar (Figs 4 to 6). The temperature-dependence of $\mathrm{k}$ was evaluated using Arrhenius equation as shown by the graph in Fig. 7. The apparent activation energy $(E a)$ for enzyme inactivation in the absence of sucrose was $78.13 \mathrm{~kJ} \mathrm{Mol}^{-1}$, a value higher than PPO from potato (Duangmal and Owusu Apenten, 1999) and lower than taro, Victoria grape and DeChaunac grape (Duangmal and Owusu Apenten, 1999, Rapeanu et al., 2006, Lee et al., 1983). The calculated values of the apparent activation energy $(E a)$ for enzyme inactivation in the absence and presence of sucrose at the temperature range studied showed an increase with sugar concentration. Ea values of 78.13, 80.37, 82.79 and $81.0 \mathrm{~kJ} \mathrm{Mol}^{-1}$ were found at $0,15,30$ and $40 \%$ sucrose, respectively. These results were contrary to that observed for peppermint PPO (Kavrayan and Aydemir, 2001) where the sucrose solutions at 20 and $40 \%(\mathrm{w} / \mathrm{w})$ did not protect the enzyme against heat-inactivation. Lourenço et al (1992) observed a higher stability for sweet potato PPO in the presence of 20 and $40 \%(\mathrm{w} / \mathrm{w})$ of sucrose. However, there are only few data related to activation energy in the presence of sugars for PPO from other materials. According to the present results and those of other authors the enzymes from different sources appeared to behave differently in the presence of sugars on heating. Various oxidative enzymes such as peroxidases were less susceptible to thermal inactivation when heated in different sucrose solution concentration (Chang et al, 1988, Neves and Lourenço, 1998; Neves, 2002). The protective effect of polyols on thermal denaturation of proteins is a fact; however, the mechanisms are still in discussion (Arakawa and Timashef, 1982, Neucere and St Angelo, 1985). Lee and Timashef (1981) and Arakawa and Timashef (1982) showed evidences of the proteinsolvent relationship as a stabilizing factor of the protein structure, representing the preferential interaction protein-water as a function of the sucrose concentration in the system. Several authors observed an increase in the activation energy (Ea) for denaturation with an increase in sucrose concentration for different enzymes and they suggested that some physicochemical properties alterations of the system could be due to the water structure (Arakawa and Timashef, 1982, Back et al., 1979, Lee and Timashef, 1981). 

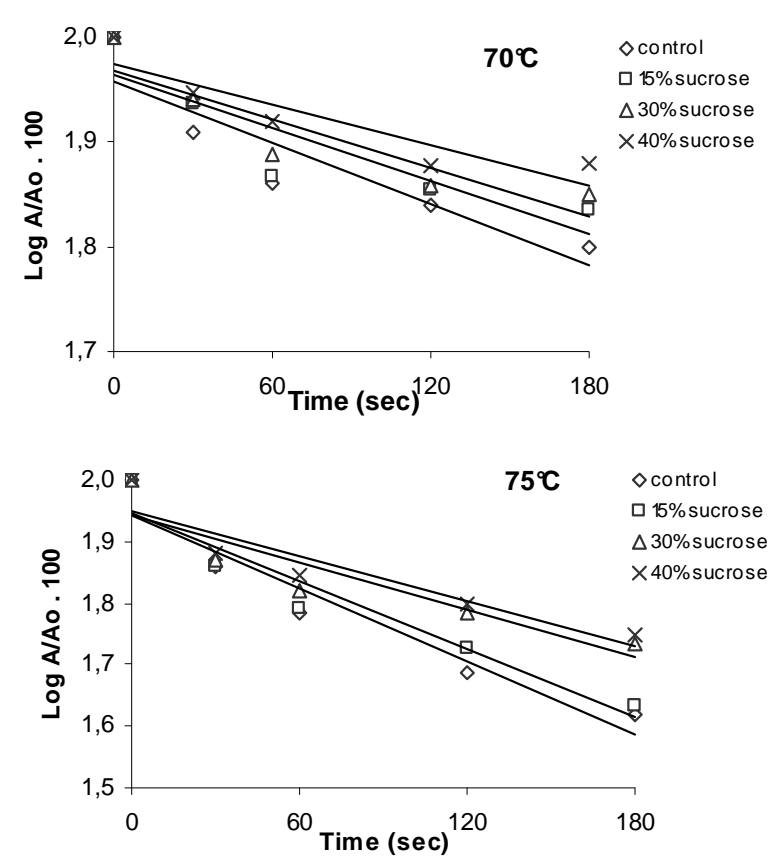

Figure 4 - Heat inactivation curves of Mentha arvensis PPO at 70 and $75^{\circ} \mathrm{C}$ in the presence of sucrose at 0, 15, 30 and 40\% (w/w) concentrations. Residual activity determined as described in methods.
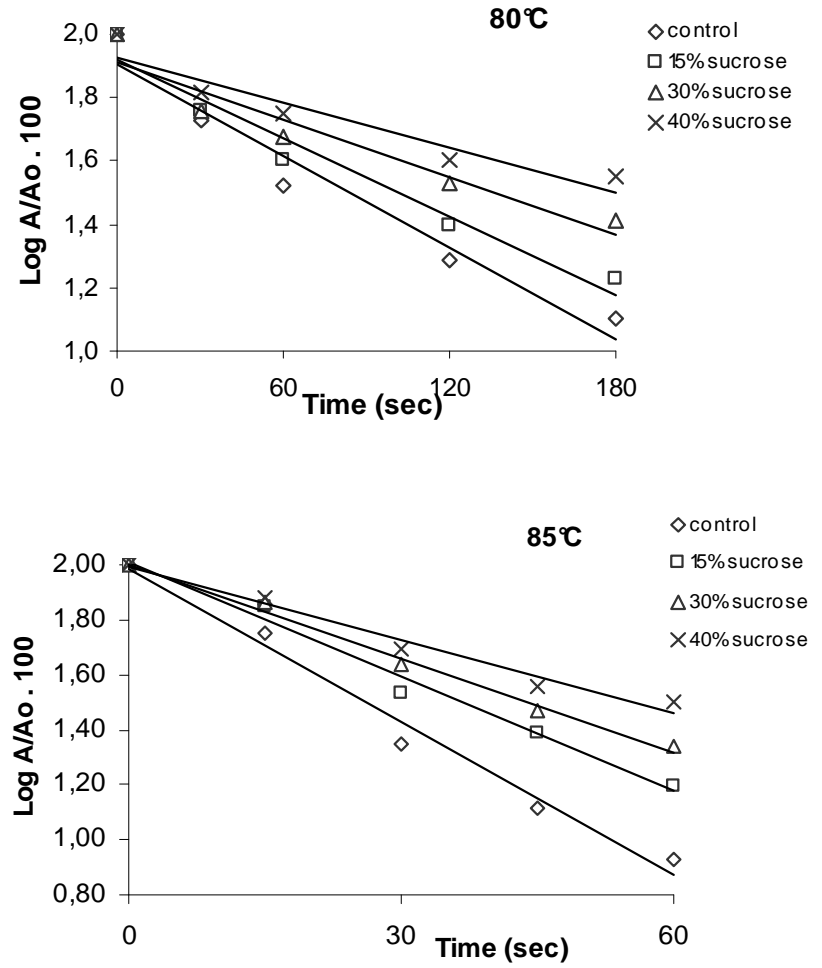

Figure 5 - Heat inactivation curves of Mentha arvensis $\mathrm{PPO}$ at 80 and $85^{\circ} \mathrm{C}$ in the presence of sucrose at $0,15,30$ and $40 \%$ (w/w) concentrations. Residual activity determined as described in methods. 


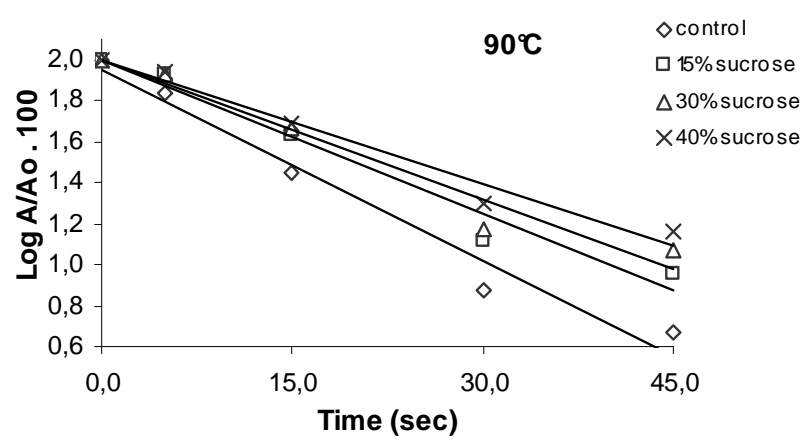

Figure 6 - Heat inactivation curves of Mentha arvensis PPO at $90^{\circ} \mathrm{C}$ in the presence of sucrose at $0,15,30$ and $40 \%$ (w/w) concentrations. Residual activity determined as described in methods.

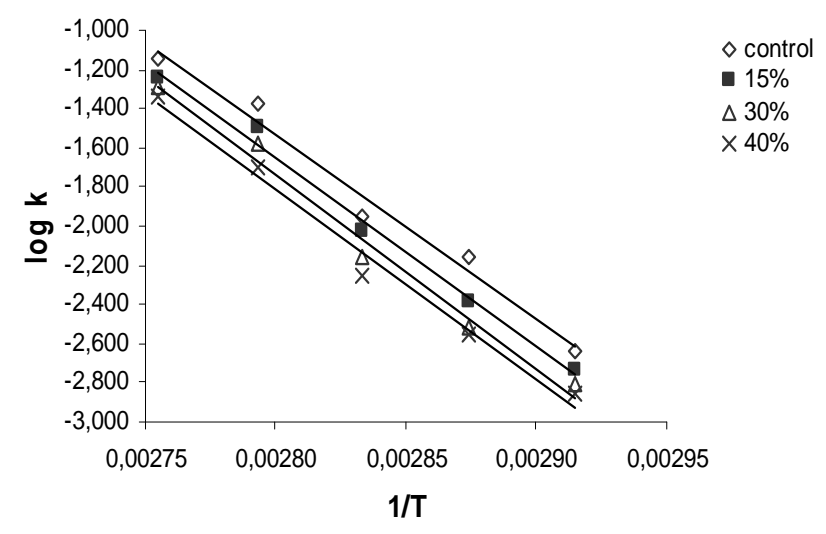

Figure 7 - Arrhenius plot for heat inactivation of the enzyme for Ea calculation.

\section{Substrate specificity and enzyme kinetics}

The extracted PPO from various sources have been shown varying substrate specificity as reported in the literature (Dogan et al., 2005; Dogan et al., 2005a, Aydemir, 2004, Lourenço et al., 1990; Concellón et al., 2004). The PPO from M. arvensis showed activity with various o-diphenols tested. The apparent $\mathrm{K}_{\mathrm{m}}$ and $\mathrm{V}_{\max }$ for the three substrates tested are present in the Table 1. Maximum activity was observed with caffeic acid, followed by 4-methylcathecol and catechol. L-tyrosine was not oxidized by the enzyme, suggesting a possible absence of cresolase activity. Resorcinol, DLDopa, pyrogallol, protocatechuic, p-coumaric, ferulic and cinnamic acids; catechin and quercetin were not oxidized by $M$. arvensis PPO (data not shown). The enzyme had a relatively high affinity towards caffeic acid, which was the the best substrate of those tested (lowest $\mathrm{K}_{\mathrm{m}}$ value). The
$\mathrm{K}_{\mathrm{m}}$ for caffeic acid was $0.825 \mathrm{mM}$ a value lower than $2.3 \mathrm{mM}$ and $5 \mathrm{mM}$ related for potato (Duangmal et al., 1999) and sweet potato enzymes (Lourenço et al., 1992), respectively. However, it compared with the value of $0.590 \mathrm{mM}$ for palmito PPO (Lourenço et al., 1990). The $\mathrm{K}_{\mathrm{m}}$ obtained for 4-methylcatechol was lower than reported for egg plant (Concellón et al., 2004), palmito stem (Robert et al., 1996), blackberry fruits (Gonzalez et al., 2000) and pear (Gauillard and RichardForget, 1997).

Lee et al. (1983) found $\mathrm{K}_{\mathrm{m}}$ values of 15.9 and 24.6 $\mathrm{mM}$, respectively, for DeChaumac grape with caffeic and 4-methylcatechol as substrate. Duangmal and Owusu Apenten (1999) reported that 4-methylcatechol was the preferred substrate for PPO from taro and potato with a $\mathrm{K}_{\mathrm{m}}$ value of 9.0 and $1.1 \mathrm{mM}$, respectively. 
Table 1 - Apparent $\mathbf{V}_{\mathrm{MAX}}$ and $\mathbf{K}_{\mathrm{m}}$ of M. arvensis PPO for three phenolic substrates

\begin{tabular}{cccc}
\hline Substrate & $\mathbf{V}_{\mathbf{M A X}} \%$ found for 4-methylcatechol & $\mathbf{K}_{\mathbf{m}}(\mathbf{m M})$ & $\mathbf{V}_{\mathbf{M A X}} / \mathbf{K}_{\mathbf{m}}\left(\mathbf{U} \cdot \mathbf{m L}^{-1} \cdot \mathbf{M}^{-1}\right)$ \\
\hline 4-methylcatechol & 100.0 & 0.928 & $56.12 \times 10^{4}$ \\
caffeic acid & 102.1 & 0.825 & $64.46 \times 10^{4}$ \\
Catechol & 74.1 & 7.41 & $52.10 \times 10^{3}$ \\
\hline
\end{tabular}

*1/V x 1/S according to Lineweaver-Burk (1934) plots.

When catechol was used as substrate the $\mathrm{K}_{\mathrm{m}}$ for $M$. arvensis PPO was close to the value of $7.51 \mathrm{mM}$, $5.0 \mathrm{mM}, 6.25 \mathrm{mM}$, and $6.8 \mathrm{mM}$ reported for PPO from Victoria grape (Rapeanu et al., 2006), litchi (Yue-Ming et al., 1997), peppermint (Kavrayan and Aydemir, 2001) and potato (Duangmal and Owusu Apenten, 1999). The apparent $\mathrm{V}_{\mathrm{m}} / \mathrm{K}_{\mathrm{m}}$ values for caffeic acid and 4-methylcatechol (Table 1) indicated a more enzymatic browning capability for the first substrate; however, the substrate catechol showed a lower affinity for PPO than the others. Victoria grape PPO (Rapeanu et al., 2006) showed higher values of specificity coefficient for chlorogenic, catechin and 4-methyl catechol, in the sequence. The $M$. arvensis PPO maintained activity when stored at $-15{ }^{\circ} \mathrm{C}$ for a period up to 30 days; it lost only $14 \%$ enzyme activity for five days and after 30 days, about $52 \%$ loss was observed. Thus, the M. arvensis PPO presented more stable than others like peppermint (Kavrayan and Aydemir, 2001) and artichoke (Dogan et al., 2005) for the same temperature and storage period. The Victoria grape PPO was very stable when stored at -80 and $-35^{\circ} \mathrm{C}$ (Rapeanu et al., 2006)

\section{Effect of inhibitors on PPO activity}

The potential of inhibition of PPO activity was verified with phenolic compounds analogue to the substrate, reducing agents and others. Table 2 shows the effect of various compounds on the activity of $M$. arvensis PPO. The most potent inhibitors were ascorbic acid and sodium metabisulfite since these compounds induced a high degree of inhibition, even at the lowest concentration used. Both inhibitors presented an initial lag phase when measuring the PPO activity. With regard to substrate analogues, cinnamic acid was the most effective inhibitor followed by pyrogallol, a trihydroxyphenol; p-coumaric and benzoic acid. EDTA did not inhibit the enzyme at concentrations up to $8 \mathrm{mM}$ while ferulic acid acted as an activator of the mentha PPO at concentrations as low as $1.5 \mathrm{mM}$ (data not shown). The inhibition was determined by a Dixon (1953) plot of $1 / \mathrm{V}$ versus [i] at two substrate concentrations (50 and $100 \mathrm{mM}$ ). The $\mathrm{Ki}$ and type of inhibition calculated are present in Table 2.

Table $2-\mathrm{K}_{\mathrm{i}}$ values and inhibition modes of the M. arvensis PPO* with different inhibitors

\begin{tabular}{lcc}
\hline Inhibitor & $\mathbf{K i}(\mathbf{M})$ & Inhibition Type \\
\hline Ascorbic acid & $0.033 \cdot 10^{-3}$ & competitive \\
Cinnamic acid & $0.078 \cdot 10^{-3}$ & competitive \\
Sodium metabisulfite & $0.042 \cdot 10^{-3}$ & competitive \\
Protocatechuic acid & $0.185 .10-3$ & competitive \\
Pyrogallol & $0,162.10-3$ & non-competitive \\
p-Coumaric acid & $1.083 \cdot 10-3$ & non-competitive \\
Benzoic acid & $1.274 .10-3$ & competitive \\
Resorcinol & $17.30 .10-3$ & non-competitive
\end{tabular}

*4-methylcatechol as substrate.

A competitive-type inhibition was obtained with ascorbic, cinnamic, protocatechuich, benzoic acid and metabisulfite. However, pyrogallol, pcoumaric acid and resorcinol showed to be non competitive- type inhibitors. Robert et al. (1997) observed a competitive-type inhibition with cinnamic and benzoic acid using 4-methylcatechol as substrate, while p-coumaric was shown to be non- 
competitive inhibitor for palmito PPO. The same was observed by Gunata et al. (1987) for grape polyphenoloxidase. Lourenço et al. (1992) reported that cinnamic and p-coumaric acids were competitive-type inhibitors of sweet potato PPO when 4-methylcatechol was used as substrate.

\section{ACKNOWLEDGEMENTS}

This study was supported by the Faculty of Pharmaceutical Sciences-UNESP Research Commission Program (PADC-FCF-UNESP).

\section{RESUMO}

Polifenoloxidase (PPO, EC 1.14.18.1) extraída de folhas de Mentha arvensis foi isolada por precipitação com $\left(\mathrm{NH}_{4}\right)_{2} \mathrm{SO}_{4}$ e diálise extensiva. Seu $\mathrm{pH}$ e temperatura ótimos variaram com o substrato. A PPO apresentou atividade com vários difenóis. Valores de $\mathrm{Km}$ foram 0,825; 0,928 e 7,41 $\mathrm{mM}$ para ácido caféico, 4-metilcatecol e catecol, respectivamente. $\mathrm{Na}$ inativação térmica, $50 \%$ da enzima foi inativada após 60 e 15 segundos a 70 e $75^{\circ} \mathrm{C}$, respectivamente. A medida de atividade residual mostrou um efeito estabilizante de sacarose a várias temperaturas e uma energia de ativação (Ea) para inativação aumentando com a concentração de sacarose de 0 a $40 \%$ (p/p). Valores de energias de ativação de 78,13; 80,37; 82,79 and $81,00 \mathrm{~kJ} / \mathrm{Mol}$ foram encontradas para 0 , 15,30 e $40 \%$ de sacarose, respectivamente. A PPO foi inibida pelos ácidos ascórbico, benzóico, cinamico, ferulico, p-cumárico, protocatéquico, além de metabisulfito de sódio, resorcinol e pirogalol. Os valores de Ki mostram que o ácido ascórbico foi o mais efetivo inibidor. O tipo de inibição foi determinado para cada inibidor.

\section{REFERENCES}

Arakawa, T. and Timashef, S. N. (1982), Stability of protein structure by sugars. Biochemistry, 21, 65366544.

Arslan, O., Temur, A. and Tozlu, I. (1997), Polyphenoloxidase form Allium sp. Journal of Agriculture and Food Chemistry, 45, 2861-2863.

Aydemir, T. (2004), Partial purification and characterization of polyphenoloxidase from artichoke
(Cynara scolymus L.) heads. Food Chemistry, 87, 5967.

Back, J. F., Oakenful, O. and Smith, M. B. (1979), Increased thermastability of proteins in the presence of sugars and polyols. Biochemistry, 18, 5191-5200.

Bradford, M. M. (1976), A rapid and sensitive method for the quantification of microgram quantities of protein utilizing the principle of protein-dye binding. Anayltical Biochemistry, 72, p.248-254.

Chang, B. S., Park, K. H. and Lund, D. B. (1988), Thermal inactivation kinetics of horseradish peroxidase. Journal of Food Science, 53, 920-923.

Concellon, A.; Anon, M.; and Chaves, A. (2004), Characterization and changes in polyphenoloxidase from eggplant fruit (Solanun melongena L.) during storage at low temperature. Food Chemistry, 88, 1724.

Duangmal, K. and Owusu Apenten, R. K. (1999), A comparative study of polyphenoloxidases from taro (Colocasia esculenta) and potato (Solanum tuberosum var. Romano). Food Chemistry, 64, 351359.

Dixon, M. (1953), The determination of enzyme inhibition constants. Biochemical Journal, 55, 170171.

Dogan, S.; Turan, Y.; Ertürk, H. and Arslan, O. (2005), Characterization and purification of polyphenol oxidase from Artichoke (Cynara scolymus L.). Journal of Agriculture and Food Chemistry, 53, 776785.

Dogan, S.; Arslan, O. and Ozen, F. (2005a), Polyphenol oxidase activity of oregano at different stages. Food Chemistry, 91, 341-345.

Gauillard, F. and Richard-Forget, F. (1997), Polyphenoloxidases from Williams pear (Pyrus communis L., cv. Williams): activation, purification and some properties. Journal of Science of Food and Agriculture, 74, 49-56.

Gonzalez, E. M., Ancos, B. and Cano, M. P. (2000),. Partial characterization of peroxidase and polyphenol oxidase activities in Blackberry fruits. Journal of Agriculture and Food Chemistry, 48, 5459-5464.

Gunata, Y. Z., Sapis, J. C. and Moutonet, M. (1987), Substrates and aromatic carboxylic acid inhibitors of grape polyphenoloxidase. Journal of Agriculture and Food Chemistry, 26, 1573-1575.

Halder, J., Tamuli, P. and Phaduri, A. N. (1998), Isolation and characterization of polyphenol oxidase from Indian tea leaf (Camellia sinensis). Journal of Nutritional Biochemistry, 9, 75-80.

Hemeda, H. M. and Klein, B. (1991), Inactivation and regeneration of peroxidase activity in vegetables extracts treated with antioxidants. Journal of Food Science, 56, 68-72.

Iyvengar, R. and Mcevily, A. J. (1992), Anti-browning agents: alternatives to the use of sulfites in foods. Trends in Food Science and Technology, 3, 60-64. 
Jiang, Yue-Ming (1999), Purification and some properties of polyphenol oxidase of longan fruit. Food Chemistry, 66, 75-79.

Kavrayan, D. and Aydemir, T. (2001), Partial purification and characterization of polyphenoloxidase from peppermint (Mentha piperita). Food Chemistry, 74, 147-154.

Lee, C. Y., Smith, N. L. and Pennesi, A. P. (1983), Polyphenoloxidase from De Chaunac grapes. Journal of Science of Food and Agriculture, 34, 987-991.

Lee, J. C. and Timashef, S. N. (1981), The stabilization of proteins by sucrose. Journal Biological Chemistry, 256, 7193-7201.

Lineweaver, H. and Burk, D. (1934), The determination of enzyme dissociation constants. Journal of the American Chemical Society, 56, 658-66.

Lourenço, E. J., Leão, J. S. and Neves, V. A. (1990), Heat inactivation and kinetics of polyphenoloxidase from palmito (Euterpe edulis). Journal of Science Food and Agriculture, 52, 249-259.

Lourenço, E. J., Neves, V. A. and Da Silva, M. A. (1992), Polyphenoloxidase from sweet potato: Purification and properties. Journal of Agricultural and Food Chemistry, 40, 2369-2373.

Martinez, M. and Whitaker, J. R. (1995), The biochemistry and control of enzymatic browning. Trends in Food Science and Technology, 6, 195-200.

Moore, B. M and Flurkey, W. H. (1990), Sodium dodecyl sulphate activation of a plant polyphenoloxidase. Journal Biological Chemistry, 265, 4982-4988.

Neves, V. A. and Lourenço, E.J. (1998), Peroxidase from peach fruit: Thermal stability. Brazilian Archives of Biology and Technology, 41,179-186.

Neves, V. A. (2002), Ionically bound peroxidase from peach fruit. Brazilian Archives of Biology and Technology, 45, 7-15.
Neucere, N. J. and St Angelo, A. J. (1985), Physicochemical properties of peanut protein in sucrose. Analytical Biochemistry, 47, 80-89.

Nicolas, J. J., Richard-Forget, F. C., Goupy, P. M., Amiot, M. J. and Aubert, S.Y. (1994), Enzymatic browning reactions in apple and apple products. Critical Review of Food Science and Nutrition, 34, 109-157.

Nunez-Delicado, E., Mar Sojo, M., Garcia-Carmona, F. and Sanchez-Ferrer, A. (2003), Partial purification of latent persimmon fruit polyphenol oxidase. Journal of Agriculture and Food Chemistry, 51, 2058-2063.

Rapeanu, G., Van Loey, A., Smout, C. and Hendrickx, M. (2006), Biochemical characterization and process stability of polyphenoloxidase extracted from Victoria grape (Vitis vinifera ssp. Sativa). Food Chemistry, 94, 253-261.

Robert, C., Rouch, C. and Cadet, F. (1997), Inhibition of palmito (Acanthophoenix rubra) polyphenol oxidase by carboxylic acids. Food Chemistry, 59, 355-360.

Tomás-Barberán, F. A. and Espín, J. C. (2001), Phenolic compounds and related enzymes as determinants of quality in fruits and vegetables. Journal of the Science of Food and Agriculture, 81, 853-876.

Vamos-Vigyazo, L. (1981), Polyphenoloxidase and peroxidase in fruits and vegetables. CRC Critical Review in Food Science and Nutrition, 15, 49-127.

Yue-Ming, J., Zauberman, G. and Fuchs, Y. (1997), Partial purification and some properties of polyphenol oxidase extracted from litchi fruit pericarp. Postharvest Biology and Tecnology, 10, 221-228.

Received: September 24, 2006 ; Revised: April 30, 2007; Accepted: July 30, 2008. 